\title{
Public Perception of Potable Water Supply in Abeokuta South west, Nigeria
}

\author{
*11 ODJEGBA EE; IDOWU $^{\mathrm{a1}}$, OA; IKENWEIWE ${ }^{\mathrm{b} 1}$, NB; MARTINS ${ }^{\mathrm{c} 1}, \mathrm{O}$; SADEEQc2, AY \\ College of Environmental Resources Management, Federal University of Agriculture, Abeokuta, \\ P.M.B. 2240, Ogun State, Nigeria \\ ${ }^{2}$ Ministry of Public Utilities and Water Resources \\ Umuahia, Abia State, Nigeria \\ a: olufemidowu@gmail.com, b: ikenweiwenb@unaab.edu.ng c: adebayo.sadiq1@gmail.com
}

KEYWORDS: questionnaire, quality, potable water, distribution network

\begin{abstract}
The perception of residents towards the supply of potable water to Abeokuta was assessed with the aid of questionnaire. Well-structured interviewer administered questionnaire were distributed across the city through the stratified random sampling method using the network distribution map obtained from the Ogun State Water Corporation as guide. Sixty - eight per cent of the respondents attested that the quality of the water supplied was unsatisfactory while $36 \%$ agreed that they had contacted water related diseases as a result of the consumption of drinking water obtained from public taps. Sixty - five per cent of the respondents use less than 120 litres of water daily, while $77 \%$ attested that the water supplied did not meet their daily demand. Only 39\% of the respondents who relied on water from alternative sources subjected the water to treatment before usage. It was advised that issues of inadequate water supply and coverage area be addressed speedily and residents should subject water obtained from alternative sources to treatment. The Corporation was also advised to pay attention to the state of infrastructure across the distribution network. CJASEM
\end{abstract}

\section{http://dx.doi.org/10.4314/jasem.v19i1.1}

\section{Introduction}

Potable water, clean environment and proper hygiene are key factors in ensuring man's survival on planet earth. However, inadequate water supply and lack of basic sanitation has resulted in grave economic and health consequences. Inadequate water supply is peculiar to developing countries (Akpor and Muchie, 2011); a situation Ali, (2012) attributes to poor water supply infrastructure, technical capacity and absence of appropriate regulatory framework. Hunter, MacDonald and Carter (2010) attests that in developing countries, about one billion people lack access to an improved drinking water supply; such that the menace of unsafe water, inadequate sanitation and hygiene results in about $88 \%$ of the 4billion annual cases of diarrheal disease; mortality and morbidity inclusive. Furthermore, the economic losses resulting from the lack of access to improved basic water and sanitation in Africa cannot be overemphasized (Aladejana and Talabi, 2013).

The three tiers of government in Nigeria are saddled with providing potable water for its citizenry. The country, though blessed with abundant surface and ground waters still struggles with inadequate water supply; a phenomenon that has led residents across Nigerian cities to rely on water from various sources such as hand dug wells, boreholes, ponds, streams, rivers etc. Potable water is supplied to Abeokuta by the Ogun State Water Corporation through the Abeokuta Water Scheme. Nevertheless, water supply to Abeokuta has been far from adequate due to the progressive decline in accessibility and reliability; an issue Odjegba et al., 2014 attributes to continuous population growth and expansion of the city. Therefore, this paper examines the perception of residents to potable water supply in Abeokuta.

Description of Study Area: Abeokuta, the capital of Ogun State, Southwest Nigeria, is situated within the rainforest belt of the tropics lying between latitude $7^{0} 06^{\prime}$ and $7^{0} 13^{\prime}$ North and longitude $3^{0} 15^{\prime}$ and $3^{0} 25^{\prime}$ East (Figure 1). It occupies a geographical area of $1256 \mathrm{sqkm}$ with a population of about 449,088 inhabitants according to 2006 Nigerian population census. The city is approximately $100 \mathrm{~km}$ north of Lagos and $80 \mathrm{~km}$ Southwest of Ibadan, the Oyo State capital. 


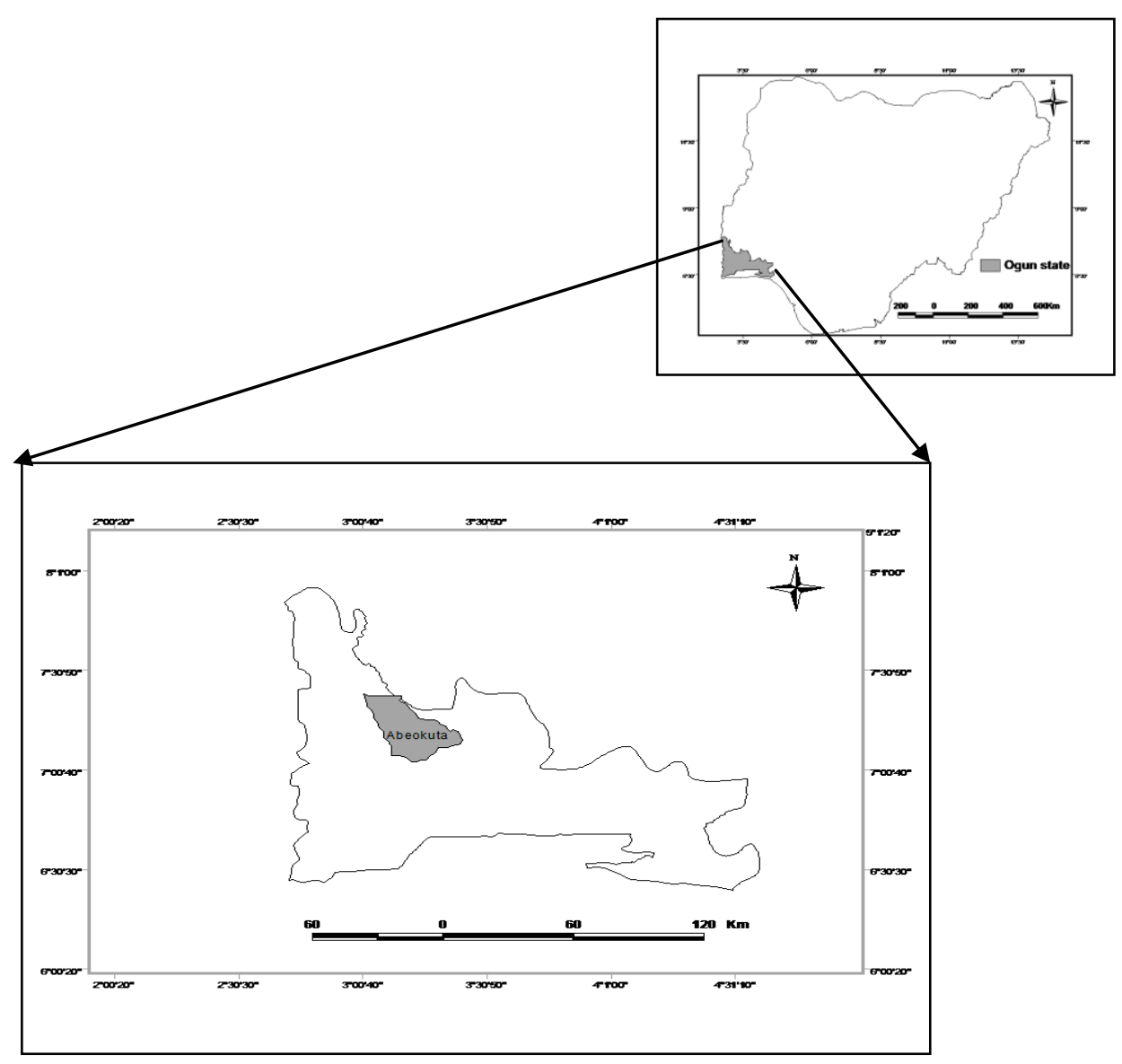

Fig 1: Map of Study Area

\section{METHODOLOGY}

Well structured interviewer administered questionnaire were distributed across Abeokuta with the aid of a network distribution map of Abeokuta obtained from the Ogun State Water Corporation. The questionnaire was distributed using the stratified random sampling and interviewer administered method (Aderibigbe, Awoyemi, and Osagbemi, 2008). The questionnaire was designed to obtain information on water related issues that includes the average volume of water consumed by respondents', adequacy and frequency of supply, water quality, and so on. Standard measurements as defined by Aderibigbe et al. (2008) were described to respondents in other to estimate the volume of water consumed. SPSS 15.0 was applied in analysing the questionnaire with the use of frequencies, percentages and measure of central tendencies (Amori and Makinde, 2012).

\section{RESULTS}

The results obtained from the questionnaire indicated that $80 \%$ of the respondents had access to tap water occasionally, $15 \%$ regularly while $5 \%$ did not have access to public water supply at all (Figure 2). Sixty eight per cent of the respondents attested that the quality of the water supplied was unsatisfactory while $32 \%$ were satisfied with the quality of water supplied. Thirty - six per cent agreed that they had contacted water related diseases during the period of consumption of water obtained from public taps while $64 \%$ said they had not contacted any disease.

More than one third of the respondents had had typhoid fever (25\%), 21\% diarrhoea, 18\% cholera, while combinations of typhoid and diarrhoea and typhoid/cholera/diarrhoea were $18 \%$ each (Figure 3 ). Over half of the respondents $(65 \%)$ use less than 120 litres of water daily. Twenty - nine per cent uses between 120 - 160 litres per day while $6 \%$ use more than 160 litres per day; and on whether the quantity of water supplied met their demand, $77 \%$ answered 'NO' leaving 23\% answering 'YES'. Eighty - two per cent of the respondents that answered 'NO' attest to the use of wells as alternative water sources (Figure 4), 9\% to boreholes; while 3\% to rivers, burst/broken pipes as well as a combination of wells and broken pipes respectively. 


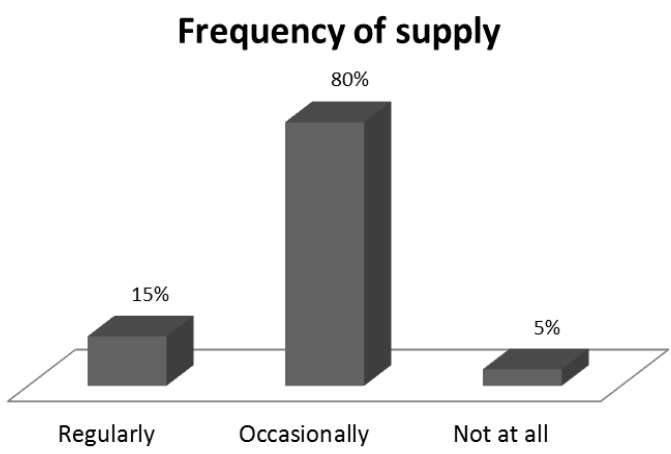

Fig 2: Frequency of water supply

\section{Alternative water sources}

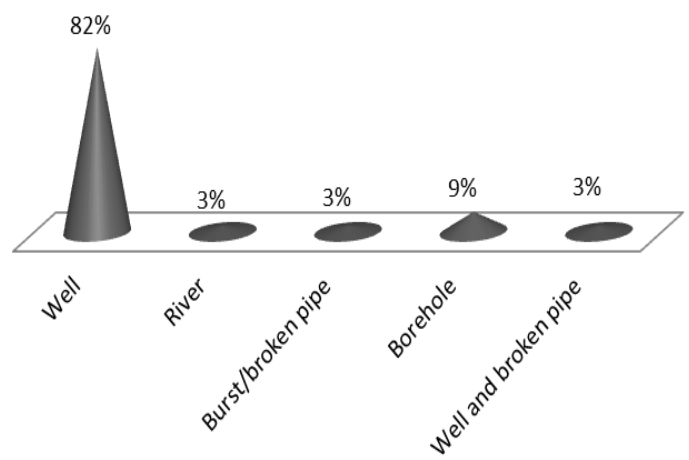

Fig 4: Use of water from alternative sources

Thirty - nine per cent of the respondents that resorted to alternative sources subjected the water to treatment before usage, with the remaining $61 \%$ using the water directly. For those that subjected the water to treatment before consumption, $83 \%$ resorted to the use of alum, $9 \%$ ordinary filtration, $4 \%$ a combination of addition of alum and ordinary filtration and $4 \%$ use Water Guard $^{\circledR}$ (Figure 5). Seventy - four per cent of the respondents stated that repair work on leaking pipes was carried out at the convenience of the workers of Ogun State Water Corporation; $16 \%$ a week later, $6 \%$ not at all and $4 \%$ immediately. Forty five per cent of the respondents rated repair work as poor, $25 \%$ rated it good, $24 \%$ satisfactory and $6 \%$ very good.

Forty - three per cent of the respondents believed that the services of Ogun State Water Corporation was good but wanted the rate of water supply to be increased, $35 \%$ stated that the service rendered was poor, $11 \%$ indicated that the service was satisfactory, while another $11 \%$ stated that the service rendered was poor and requested improvement in the services.

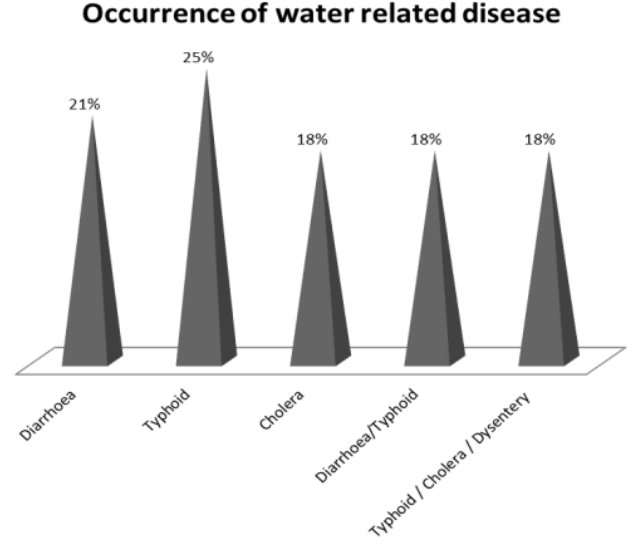

Fig 3: Occurrence of water related diseases

\section{Methods of treatment}

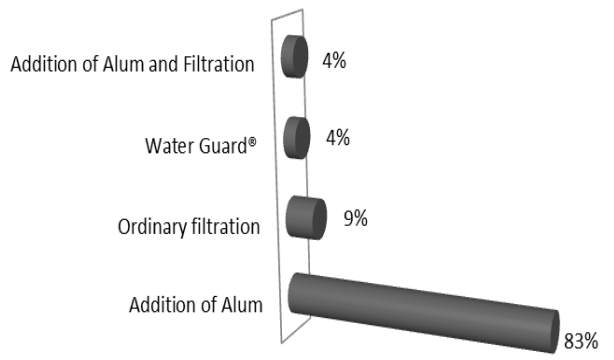

Fig 5: Methods of water treatment

\section{DISCUSSION}

The response in the questionnaire shows that the problem of public water supply in Abeokuta metropolis is a compound one. First, there is the problem of coverage area as very few respondents had the luxury of having public taps close to their home let alone taps running inside their houses. Secondly, there is the problem of irregular water supply (Gbadebo and Akinhanmi 2010); as only $12.5 \%$ of the respondents reportedly had regular water supply weekly and thirdly, there is the question of purity of water supplied. These outlined problems are not peculiar to Ogun State Water Corporation or Abeokuta metropolis alone as Aderibigbe, et al. (2008) and Alabi - Aganaba and Osagbemi (2005) stated that a lot of people in Ilorin had epileptic water supply and usually went without water for days. However, Falkenmark (1994) had a contrary report stating that in developing countries (of which Nigeria is one) water only ceases to run in taps on very rare occasion.

The heavy reliance on water from alternative source has its attendant effect on the population. Aderibigbe 
et al. (2008) stated that non- availability of adequate water usually has its consequences vis - a -viz water related diseases. Rottier and Ince (2003), Alabi Aganaba and Osagbemi (2005) and John-Dewole (2012) reported that water from sources such as rivers are usually contaminated and often times unfit for human consumption.

According to Gleick (1996), water is said to be adequate when supplied in the right quantity to meet all the uses it is meant for. In his study, Gleick determined that a daily supply of 140 -160 litres per capita per day is considered adequate to meet all domestic needs. However, only $29 \%$ of the respondents in this study reportedly had access to 140 -160 litres per day, leaving $65 \%$ living on less than 140 litres per day for all purposes comprising of domestic, agricultural and industrial uses. This calls for serious attention as the daily requirement of water for domestic purposes alone is estimated to be about 50 litres per person (Park, 2002 and Gleick, 1996).

The $66.5 \%$ unsatisfactory response on the quality of water supplied did not come as a surprise as, the option of interviewer administered questionnaire gave the opportunity of interacting with some respondents, some of which reported the presence of sediments at the bottom of containers holding large quantities of the water supplied. However, only $36 \%$ stated that they have contacted one disease or the other during the period of consumption of the water and this is conforms to Okonko, et al., (2008) that the consequences of water borne bacteria and virus infection: polio, hepatitis, cholera, typhoid, diarrhoea, stomach cramps etc. have been established. Nonetheless, it is strongly believed that more respondents would have suffered from water related diseases than the $36 \%$ that admitted to the diseases. Oluwasanya (2009) attributes the 'denial' of diseases to the 'God forbid' syndrome. The 'God forbid' syndrome refers to the concept of people; especially Africans denying the fact that they have or are suffering or can suffer from a disease. Consequently, diarrhoea, typhoid, cholera as well as dysentery (which come with stomach cramps and stooling) are diseases the respondents have reportedly had as a result of the consumption of this water.

Conclusion and Recommendation: It is important that the problem of water supply in Abeokuta is addressed. It was discovered from the responses obtained that the daily water supply is the not sufficient to meet the need of the constantly growing populace. There is also the issue of inadequate distribution/coverage area; as there were respondents that did not have access to public water supply, with some living in areas that used to have but are now cut off from the distribution line.
Also, while the uses of water from alternative sources especially for household uses like drinking and cooking as well as the development of self - supply systems is encouraged to cover for the shortfall, it is highly advised that people should pay attention to the quality of the water by subjecting it treatment methods like boiling, filtering, use of alum etc.

The Ogun State Water Corporation should pay attention to the state of its infrastructure across the city. There should be constant monitoring of the pipe distribution network to check for leakages and for prompt repairs when discovered. It also important for members of the public to report cases of pipe vandalism and destruction so that the quality of the water in the distribution network is preserved.

\section{REFERENCES}

Aderibigbe, S. A., Awoyemi, A. O., and Osagbemi, A. O. "Availability, Adequacy and Quality of Water Supply in Ilorin Metropolis, Nigeria." European Journal of Scientific Research. 23, no.4 (2008):528 - 536 ISSN 1450-216X

Akpor, O. B. and Muchie, M. "Challenges in Meeting the MDGs: The Nigerian Drinking Water Supply and Distribution Sector." Journal of Environmental Science and Technology. 4, no. 5 (2011):480-489. doi: 10.3923/jest.2011.480.489

Alabi - Aganaba, D. and Osagbemi, G. K. (2005) "Sources and Utilization of Water in two selected Communities in Ilorin East Local Government Area of Kwara State." African Journal of Clinical Experimental Microbiology. 1, no.7 (2005): 11-16.

Aladejana, J. A. and Talabi, A. O. "Assessment of groundwater quality in Abeokuta South-western, Nigeria." International Journal of Engineering and Science. 2, no.6 (2013):21 - 31

Ali, K. A. "Development of Water Supply Infrastructure in Nigeria: Challenges and Prospects." Delivered at the 2012 Nigerian Society of Engineers October Lecture. October 04, 2012 Accessed on 12/10/14 and Available at www.nse.org.ng

Amori, A. A. and Makinde, A. A. "Evaluation of Access to Public Water Supply in Two Major Cities in Nigeria." American Journal of Environmental Engineering. 2, No 6 (2012):148151. doi: 10.5923/j.ajee.20120206.01

Falkenmark, M. "Population, Environment and Development; A water perspective." Proceedings 
of the United Nations expert group meeting on regulation, environment and development. New York, United Nations (1994):99 - 116pp

Gbadebo, A. M. and Akinhanmi, T. F. "Gender issues in management and use of groundwater resources: a case of Abeokuta metropolis." Journal of Applied Sciences in Environmental Sanitation. 5, no.2 (2010):191 $\quad 199$. https://www.trisanita.org/jases/asespaper2010/as es18v5n2y2010

Gleick, P. "Basic water requirements for human activities: Meeting basic needs." International Water. 21, no.2 (1996): $83-92$. www.pacinst.org

Hunter, P. R., MacDonald, A. M. and Carter, R. C. "Water Supply and Health." PLos Medicine. 7, no 11 (2010) doi: 10.1371/journal.pmed.1000361

John-Dewole, O.O. Adverse Effects of Inadequate Water Supply on Human Health: a case study of Kajola Local Government in Oyo State, Nigeria Greener Journal of Medical Sciences 2, no.5 (2012):115-119 ISSN: 2276-7797

Odjegba, E. E., Idowu, O. A., Oluwasanya, G. O., Ikenweiwe, N. B. and Martins, O. "Assessment Of Water Demand and Seasonal Variation of Bacteriological Content of Public Water Systems in Abeokuta, Nigeria." Conference Proceedings of the $7^{\text {th }}$ Annual Institute of Ecology and Environmental Studies International Conference, June 24 - 26, 2014, Obafemi Awolowo University, Ife, Nigeria 7, (2014):256 - 262
Okonko, I. O. Adejoye, O. D. Ogunnusi, T. A. Fajobi, E. A. and Shittu, O. B. Microbiological and physicochemical analysis of different water samples used for domestic purposes in Abeokuta and Ojota, Lagos State, Nigeria. African Journal of Biotechnology 7, no.5 (2008):617 - 621.

Oluwasanya, G. O, Better Safe than Sorry: Towards Appropriate Water Safety Plans for Urban Self Supply Systems in developing countries. PhD. Thesis, Cranfield University, UK, (2009):459 pp.

Park, K. "Environment and Health Textbook of Preventive and Social Medicine." M/S (Babarsidas Bhanot Publishers,2002), India $500 \mathrm{pp}$

Rottier, E. and Ince, M. Controlling and preventing diseases. Water Engineering and Development Centre, Loughborough University, UK (2003): $220-248$ 